\title{
TAENIOCOTYLE NOM. NOV. FOR MACRASPIS OLSSON, 1869, PREOCCUPIED, AND SYSTEMATIC POSITION OF THE ASPIDOBOTHREA
}

\author{
HORACE W. STUNKARD
}

The American Museum of Natural History, New York, and the Marine Biological Laboratory, Woods Hole, Massachusetts ${ }^{1}$

Olsson (1869) erected the genus Macraspis to receive a new species, M. elegans, from the gall-bladder of Chimaera monstrosa, taken at the Skagerrack, in the North Sea. Stiles and Hassall (1908) and Neave (1940) noted that the generic name Macraspis Olsson, 1869 was preoccupied by Macraspis MacLeay, 1819 and consequently a homonym. To replace it I propose the name Taeniocotyle (tainia, ribbon, fillet; kotylēe, cavity, acetabulum) with Taeniocotyle elegans (O1sson, 1869) as type species.

Taeniocotyle is a member of the family Aspidogastridae, order Aspidobothrea Burmeister, 1856. Monticelli (1892) renamed the group Aspidocotylea and Faust and Tang (1936) proposed the name Aspidogastrea. Commenting on the latter action, Hyman (1951, p. 248) remarked, "Faust and Tang have proposed a new name Aspidogastrea for the group on the ground that the name has to be derived from the genus Aspidogaster. This ground is mistaken. There are no rules governing the formation of names of higher taxonomic categories, and the creator of an order or class is at liberty to select any name he pleases. The author is strongly opposed to the invention of new names for groups for which names already exist." The argument against the change of name by Faust and Tang applies with equal force to the change proposed by Monticelli. Repeating a common and widely held opinion, Najarian (1961, p. 515) stated, "It is generally accepted that the subclass Aspidogastrea Faust and Tang, 1936 represents a group of worms intermediate in morphology and life history between monogenetic and digenetic trematodes." Hyman has disposed of the nomenclatorial issue and critical evaluation of data shows that the aspidogastrids are not intermediate in either morphology or life-history between the monogenetic and digenetic trematodes.

On July 13, 1961, Dr. James W. Campbell of the Rice University gave the writer a live specimen, identified as Macraspis cristata, from the gall-bladder of the northern stingray, Dasyatis centrura, taken near Woods Hole, Massachusetts. It tended to coil in spiral fashion with the adhesive organ on the external aspect. Other specimens had been taken from $D$. centrura in previous summers by members of the Rice University group at the Marine Biological Laboratory, Woods Hole. Five were made available for study by Dr. John E. Simmons, Jr., now at Emory University, Atlanta, Georgia, and three by Dr. John S. Laurie, now at the University of Utah, Salt Lake City, Utah. The latter specimens measured 218, 246,

${ }^{1}$ Mailing address: The American Museum of Natural History, Central Park West at 79th Street, New York 24, N. Y. 


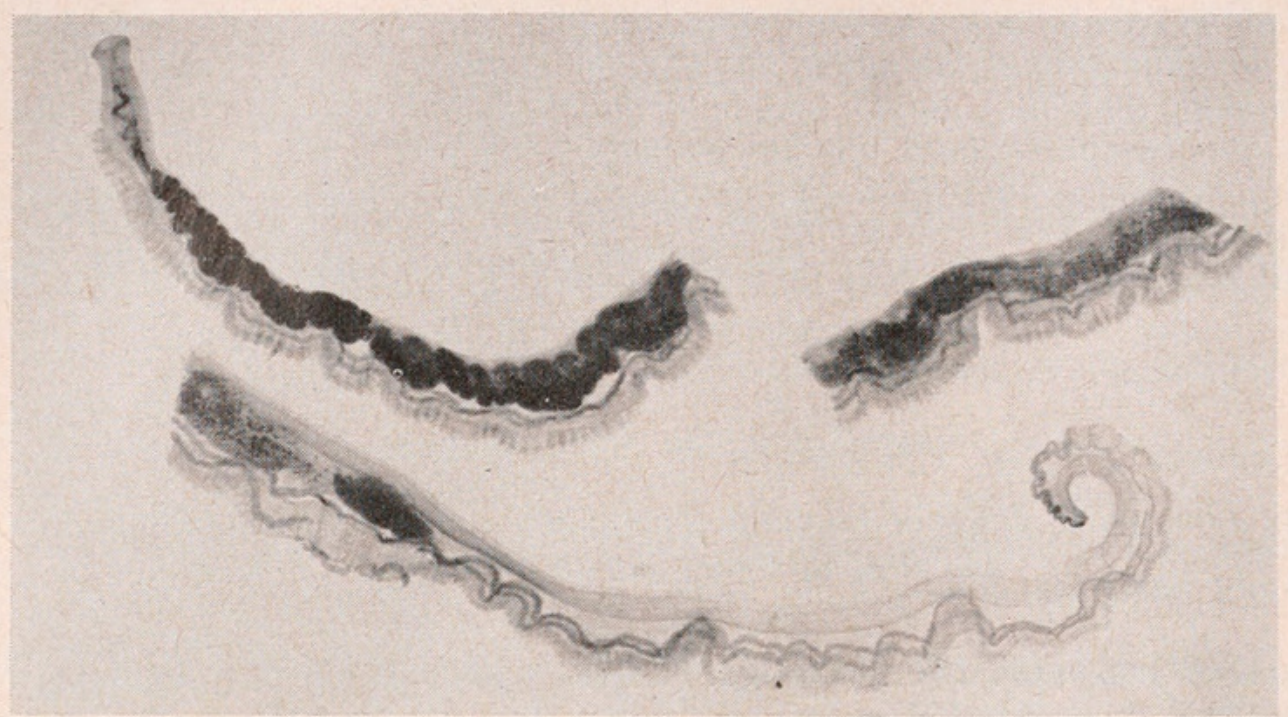

Figure 1. Multicalyx cristata from Dasyatis centrura; specimen $65 \mathrm{~mm}$. long.

and $256 \mathrm{~mm}$. in length. Grateful acknowledgment is made to the members of the group for their kindness and generosity. The record of collection provided by Dr. Laurie, reads :

1958-June 30, 2 specimens from the gall-bladder; after fixation, 290 and $305 \mathrm{~mm}$. in length and $3 \mathrm{~mm}$. in depth; the "foot" is bright red in the living worm.

1959 -July 6, 2 specimens from the gall-bladder.

1959-July 8, 2 specimens from the gall-bladder.

1960 - July 12, 3 specimens from the gall-bladder.

1960 - July 16, 4 specimens from the gall-bladder.

1961-July 13, 1 specimen from the gall-bladder.

The specimen taken in 1961 (Fig. 1) was relaxed, flattened, fixed, stained and mounted. When compressed, the worm was flattened laterally and presents a side view of the body and a clear view of Laurer's canal and its opening on the dorsal surface. The worm is $65 \mathrm{~mm}$. long and has about 400 alveoli in the "foot"

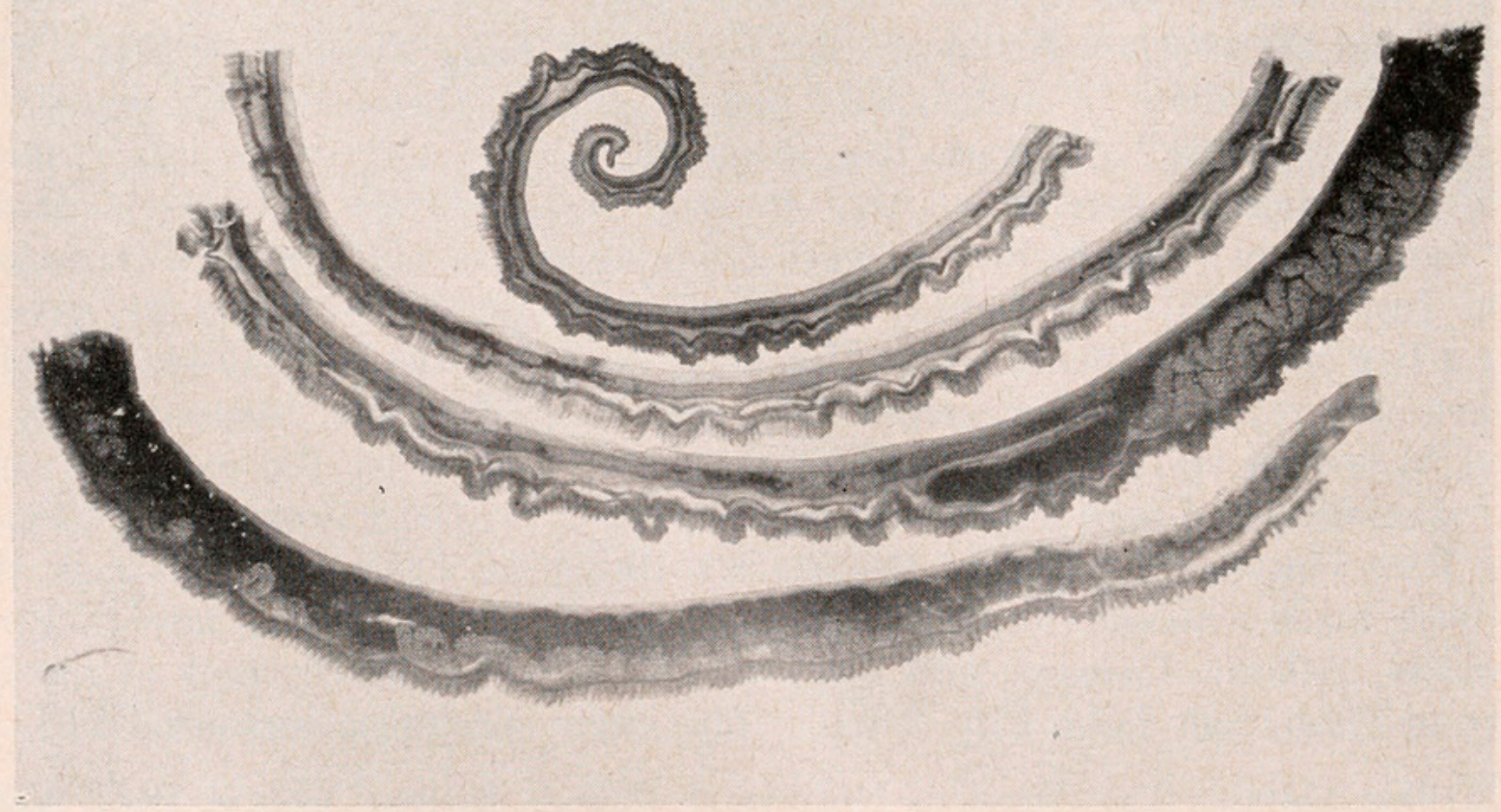

Figure 2. Multicalyx cristata from Dasyatis centrura; specimen $182 \mathrm{~mm}$. long. 
or adhesive organ, although they grow progressively smaller toward the posterior end of the body where new ones are added. In this worm the posterior end of the body is rounded, but in other, larger specimens the region behind the adhesive organ forms a bluntly conical tip which is turned dorsally at a right angle (Figs. 2,3 ). In the worm shown in Figure 1, the pharynx is $0.56 \mathrm{~mm}$. in diameter. The testis is $2.75 \mathrm{~mm}$. long, $0.81 \mathrm{~mm}$. in dorsoventral measurement, and slightly behind the middle of the body. The sperm duct passes forward on the ventral side of the body; at the level of the anterior end of the adhesive organ it expands to form a coiled seminal vesicle and the terminal portion of the duct, inside the cirrus sac, is surrounded by secretory cells. The cirrus sac is small, $0.40 \mathrm{~mm}$.

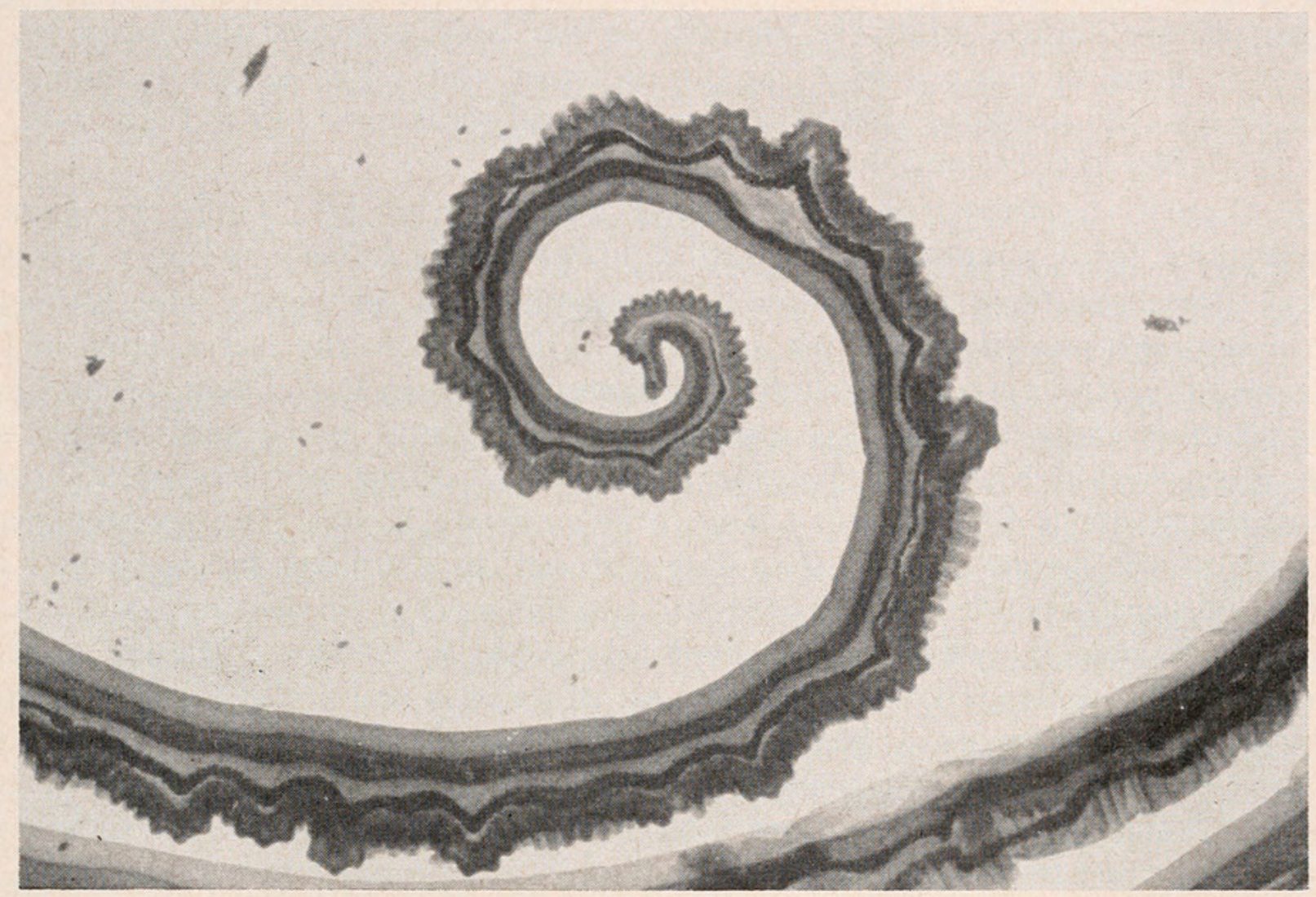

Figure 3. Same specimen as Figure 2; reversed in photograph, to show the posterior end of the worm. The smaller specks in the photograph are eggs of the parasite.

long, $0.30 \mathrm{~mm}$. wide, with a relatively weak muscular wall. The common genital pore is ventral, below the posterior end of the pharynx. The ovary is ovate to pyriform, $0.48 \mathrm{~mm}$. long and $0.36 \mathrm{~mm}$. in dorsoventral measurement, situated about one-fourth of the body length from the anterior end. The vitellaria consist of cords of follicles which extend in the ventrolateral areas from an anterior limit about $7 \mathrm{~mm}$. from the anterior end of the body to almost the posterior end. Individual follicies are spherical to oval and measure from 0.06 to $0.095 \mathrm{~mm}$. in diameter. The ootype region agrees with other descriptions of the species, and Laurer's canal opens to the surface a short distance posterior to the ovary. The uterus, which courses in coils posteriad from the ootype to the level of the testis and then forward to the genital pore, is filled with an enormous number of eggs. In the initial portion of the uterus the eggs are thin-shelled and more spherical whereas in the later loops the eggs become heavy-shelled, with flattened opercular ends and 
antopercular ends that are thickened and may bear small knobs. Eggs measure 0.12 to $0.14 \mathrm{~mm}$ in length and 0.062 to $0.074 \mathrm{~mm}$ in width.

Other specimens collected in previous years are much larger; the largest ones available for this study are 180 to $256 \mathrm{~mm}$. in length. The worm shown in Figure 2 is $182 \mathrm{~mm}$. long, and has over 800 alveoli. The pharynx is $0.625 \mathrm{~mm}$. in diameter. The testis is $5.6 \mathrm{~mm}$. long, $1.24 \mathrm{~mm}$. in greatest depth, and is situated at the anterior end of the second third of the body. In the largest specimen, the testis is at the posterior end of the anterior third of the body. In the specimen shown in Figure 2, the cirrus-sac is $0.57 \mathrm{~mm}$. long and $0.38 \mathrm{~mm}$. in diameter. The ovary is $1.00 \mathrm{~mm}$. long, $0.75 \mathrm{~mm}$. deep, and is situated about one-sixth of the body length from the anterior end, about midway between anterior end and the testis. It is apparent that the gonads are shifted relatively forward as the body enlarges and increases in length and more alveoli are added at the posterior end. The eggs are somewhat larger than in the specimen shown in Figure 1 , and measure 0.135 to $0.153 \mathrm{~mm}$. in length by 0.080 to $0.094 \mathrm{~mm}$. in width.

Dr. Laurie reported (in littoris) that according to Dr. James E. Lynch, "Macraspis is fairly abundant in the ratfish (Hydrologus colliei) in Puget Sound."

The specimens from $D$. centrura are determined as specifically identical with the single worm reported by Faust and Tang (1936) from the spiral valve of the cow-nosed ray, Rhinoptera quadriloba (Le Sueur) taken in Biloxi Bay, Mississippi. Since all other individuals of this species have been found in the gall-bladder, the location reported by Faust and Tang is questionable. Faust and Tang (1936) described the worm as Stichocotyle (Multicalyx) cristata n. sp. The specimen was assigned to the genus Stichocotyle but differed in fundamental respects. So Stichocotyle was expanded and divided into two subgenera: Stichocotyle, and a new subgenus, Multicalyx, which was erected to receive S. cristata. Manter (1954) transferred the species, cristata, to the genus Macraspis and Dollfus (1956) listed Multicalyx as a synonym of Macraspis. Discussing the alteration of the generic diagnosis of Stichocotyle and subdivision of the genus, Brinkmann (1957, p. 14) stated, "All this systematic nonsense is accordingly useless and in fact those two characteristics : 1) the acetabular structure, and 2) the presence of a single testis, in which Faust and Tang find that their species differs from Stichocotyle, and for which they emend the diagnosis of the latter genus, are just the characteristics which it shares with the genus Macraspis." Brinkmann noted differences between $M$. elegans and $M$. cristata which preclude their identity. Referring to the account of Faust and Tang, Dollfus (1958, p. 227 ) stated, "L'espèce était évidemment nouvelle, mais il est incompréhensible que Faust \& Tang l'aient placée dans Stichocotyle, alors que c'est manifestement un Macraspis; toutefois, Faust \& Tang ont proposé un nouveau sous-genre: Multicalyx. Ce sous-genre a été considéré par H. W. Manter (1954, p 482), R. Ph. Dollfus (1956, p. 12), Aug. Brinkmann (1957, pp. 13, 17), comme simplement un synonyme de Macraspis." The citation in the title of Dollfus' (1958) paper, “Macraspis cristata (E.-C. Faust et C.-C. Tang, 1936) H.-W. Manter 1936," is obviously an error of transcription since Dollfus gave the correct date, Manter, 1954, in the text.

As noted, previous authors have considered Multicaly $x$ to be synonymous, at least in part, with Macraspis Olsson, 1869. The species, elegans, is type of the generic concept represented by the preoccupied name Macraspis, now Taeniocotyle, 
while cristata was named type of the subgenus, Multicalyx. If the species elegans and cristata are regarded as congeneric, Multicaly.x would replace Macraspis (preoccupied), but such action would create a vexatious nomenclatorial problem. Multicalyx cristata is type of the subgenus, now raised to generic rank, but the genus originally had the species elegans as type. A genus can not have two type species, but the differences between the species elegans and cristata are of sufficient magnitude to warrant the elevation of Multicalyx to generic status, with resolution of the taxonomic difficulty and the addition of a tenth genus to the nine recognized by Dawes (1941) as members of the family Aspidogastridae. Comparison of $T$. elegans as depicted by Jägerskiöld (1899) and Brinkmann (1957) with the descriptions of M. cristata by Faust and Tang (1936), Dollfus (1958), and the present specimens, discloses differences in host and geographic distribution, in size and form, in manner of growth (the proliferative zone is pretesticular in T. elegans and posttesticular in $M$. cristata), in extent of uterus, and in location of the gonads, especially the testis. These differences appear adequate to distinguish between two generic concepts.

Three immature specimens of Macraspis, probably $M$. elegans, were found by Manter (1931) in the intestine of a southern kingfish, Menticirrhus americanus, taken near Beaufort, North Carolina. From their location, the worms had apparently been ingested with food of the host, which according to Breder (1929) consists largely of invertebrates and small fishes, and which led Brinkmann (1957) to suggest that $M$. americanus may serve as a transmitting agent for Macraspis. Manter (1954) listed M. elegans from the gall-bladder of Callorhynchus milii taken in New Zealand waters and reported a second species of Macraspis, represented by worms taken previously from the gall-bladder of an undesignated "dogfish" by students at Victoria University College, Wellington, N. Z. Two specimens each measured $43 \mathrm{~mm}$. in length, with about 300 acetabula, the testes near the middle of the body, the ovary about one-seventh of the body length from the anterior end, and the eggs measured 122 to 132 microns in length by 81 to 96 microns in width. Dollfus (1958) referred these specimens to M. cristata; also others from the gall-bladder of Mustelus (Cynias) canis (S. L. Mitchill) taken near Dakar, Senegal. The largest of these worms measured $113 \mathrm{~mm}$. long, $2.5 \mathrm{~mm}$. wide and $3.0 \mathrm{~mm}$. thick. In a postscript, Dollfus reported receipt of numerous additional specimens found in the gall-bladders of Scoliodon terrae-novae and Rhinobatus cemiculus, taken near Gorée, Sénégal. In an earlier paper, Dollfus (1956) had divided the family Aspidogastridae into two subfamilies: Aspidogastrinae and Macraspidinae. Because of new information from the African material, Dollfus (1958) revised his diagnosis of the subfamily Macraspidinae, but the suppression of Macraspis as a homonym eliminates the name of the subfamily and, indeed, the division of the family serves no useful purpose.

The aspidogastrid trematodes have been the subject of controversy for more than a century. The type species, Aspidogaster conchicola von Baer, 1827, lives in the pericardial and renal cavities of fresh-water mussels in Europe, North America, and China, and has been reported from the digestive tracts of various fishes and turtles that presumably acquired the worms by eating infected mollusks. How long the worms can survive in such predator hosts is unknown, but Van Cleave and Williams (1943) recorded a period of fourteen days after introducing the 
worms into the stomach of a turtle, Pseudemys troosti. A number of other species have been described from molluscan, piscine and chelonian hosts, and were arranged in nine genera by Dawes (1941). All are members of the family Aspidogastridae Poche, 1907.

The first realistic classification of the trematodes was made by Burmeister (1856) who arranged them in three groups: (1) Pectobothrii (pēktos, compact, firm; bothros, pit) with firm, hard suckers; (2) Malacobothrii (malakos, soft) with soft, flexible suckers; and (3) Aspidobothrii (aspis, shield) with multiloculate adhesive organs. Van Beneden (1858) divided the Trematoda into two groups: "Monogeneses," those with a single sexual generation, and "Digeneses," those in which a sexual generation alternates with asexual generations. The names applied to the two groups were latinized by Carus (1863) as Monogenea and Digenea. Van Beneden made no attempt to allocate the Aspidobothrii, but early authors generally included the aspidogastrids in the Digenea, although it was known from the studies of Aubert (1855), Voeltzkow (1888) and others that Aspidogaster conchicola at least and perhaps others, did not have asexual generations in the lifecycle.

Development of knowledge concerning the life-cycle of the trematodes was complicated by erroneous postulates. After alternation of generations in certain lower invertebrates was established by Steenstrup (1842) and the discovery of the developmental cycle of Fasciola hepatica by Leuckart (1882) and Thomas (1883), alternation of generations in the Digenea appeared firmly established. However, Grobben (1879) and (1882), after demonstration of parthenogenesis in other invertebrates, concluded that the life-cycle of trematodes does not involve an alternation of sexual and asexual generations, but is heterogonic, the sexual generation alternating with parthenogenetic ones. This idea was adopted by Sinitsin (1911) who designated the generations in the molluscan host "Parthenita" in contrast to the sexual generation which he termed "Marita." Stunkard (1940, p. 6) stated, "So far as I am aware, parthenogenesis has never been established by critical and competent methods in either sporocysts or rediae, and the best recent work has shown that in several species it does not occur." The terminology has been espoused by many authors and still persists. Odening (1960) employed the terms although Schäller (1960), in the same number of the same journal showed that reproduction in the intermediate host is strictly asexual.

Although alternation of generations was widely accepted in the life-cycles of the Digenea, there were certain anomalies. The life-history of the holostomes appeared to be an exception, since no sporocyst or redial stages had been observed and the encysted tetracotyliform larvae developed sexual maturity in vertebrate hosts. In the first edition of his "Parasiten des Menschen," Leuckart (1863) voiced the suspicion that the embryo of the holostomes may develop directly into the tetracotyle. The larva which emerges from the egg was first designated a miracidium by Braun (1893). The idea was accepted by von Linstow (1877) who pointed out that such a method of development is distinct from monogenetic and digenetic cycles and appears to be intermediate between them. Leuckart (1889) adopted the theory of von Linstow and termed the development of the holostomes "Metastatic," i.e., intermediate between monogenetic and digenetic. This concept was endorsed by Brandes (1890) and other authors who believed that the larvae long 
known as "Tetracotyle" and "Diplostomum" developed by metamorphosis of the miracidium without sporocyst or redial generations. It persisted until Lutz (1921), Mathias (1922) and Ruszkowski (1922), independently, showed that the tetracotyliform larvae develop from furcocercous cercariae and that the life-cycle is strictly digenetic. Actually, there is no intermediate condition between monogenetic and digenetic and the concept "Metastatica" of Leuckart was based on a false presumption.

Monticelli (1888) arranged the digenetic trematodes into four families and included Aspidogaster in the family Amphistomeae. Shortly thereafter Brandes (1890) divided the Diplostomeae of Monticelli into three families: Diplostomidae, Hemistomidae, and Holostomidae. The anomalous position of the aspidogastrids, and the acceptance of metastatic development of the tetracotyliform larvae, made the division of the trematodes into Monogenea and Digenea somewhat incongruous and artificial. Accordingly, Monticelli (1892) reverted to the scheme of Burmeister, and divided the order Trematoda into three suborders: Heterocotylea, Aspidocotylea, and Malacocotylea. Actually, the result was to divide the Digenea into the Aspidocotyles and Malacocotylea, since the Heterocotylea was equivalent to the Pectobothrii. Discussing the situation, Braun (1893) noted that the aspidogastrids are monogenetic but morphologically like the distomes, whereas Gyrodactylus is not monogenetic although it is morphologically like the polystomes. He stated (p. 889), "Es ist aber sehr fraglich, ob wir berechtigt sind, ein System der Trematoden ausschliesslich auf ihre verschiedene Entwicklungsweise zu grunden; abgesehen davon, dass dieselbe bei vielen Gattungen absolut unbekannt ist, demnach die Einfügung derselben in das System nach ganz anderen Gesichtspunkten vorgenommen werden muss, folgen wir sonst nirgends diesem Princip ausschliesslich und haben es bei den Monogenea resp. Gyrodactylus mit Recht nicht befolgt; ja wir stellen es ziemlich in den Hintergrund, da seine alleinige Anwendung bei der nicht selten recht verschiedenen Entwicklungsweise notorisch nahe verwandter Arten resp. Gattungen zu sehr sonderbaren Systemen führen müsste."

Jägerskiöld (1899) discussed the anomalous condition of the aspidogastrids and Odhner (1902) showed that in general morphology they agree substantially with the digenetic distomes. Stunkard (1917) reviewed the literature pertaining to the family, described Cotylaspis cokeri Barker and Parsons, 1914 from the intestine of Malacoclemmys lesueurii, and discussed the morphology of the group. Concerning its systematic position he stated (p. 82), "Whether the Aspidogastridae are primitive forms or secondarily degenerate is at yet undecided. The simple and archaic character of the intestine, the eye spots, the direct development and the ectoparasitic habit as it occurs in the family, together with the parasitic infection of mollusks by adult forms strongly suggests a very primitive and ancient group. It is probable that complete evidence concerning the structure and life-history of this family would go a long way toward solving the problem of whether the invertebrate or the vertebrate is the original host and the attendant problem of the origin of double hosts." In this connection, Leuckart (1879) compared Archigetes, a progenetic cestode which becomes sexually mature in tubificid annelids, with Aspidogaster and suggested that the aspidogastrids are essentially sexually mature rediae.

Studies by different authors on development of members of the family provide 
data of systematic value. Voeltzkow (1888) reported that as it emerges from the egg, the young Aspidogaster conchicola is a distome, with a simple posterior sucker. In the sucker, the septa which produce the multiloculate condition are developed internally and the organ is then everted to form the shield-shaped adhesive disk. Other accounts were made by Faust (1922) and Williams (1942). According to Faust, on emergence from the egg, the larva has paired clusters of cephalic glands whose ducts open just anterior to the oral sucker. He stated that these glands are analogous to the salivary glands of the redia of Cercaria equitator Sinitsin, 1911 and could lend support to the view that the aspidogastrid is a redia. Further data were provided when Odhner (1898) showed that Stichocotyle nephropis Cunningham, 1884, which was described from larvae encysted on the intestinal wall of Nephrops norvegicus, becomes adult in the bile ducts of the liver of rays, Raja clavata. This discovery showed that $S$. nephropis has at least two hosts in the life-cycle, but the manner in which the lobster becomes infected is yet undisclosed. Nickerson (1895) reported the species encysted on the intestine of the American lobster, Homarus americanus. Cotylaspis insignias Leidy, 1856, is a parasite of various unionid species in North America. Stunkard (1917) reported it from Unio pustulosis, Lampsilis gracilis, and four species of Anodonta. Osborn (1904) gave an account of the distribution, habits, and anatomy of the species and described a young individual which had a simple ventral sucker, no eye-spots, and two entirely distinct and separate excretory systems and pores. This condition of the excretory system is identical with that in rediae and very young cercariae of the Digenea and according to Osborn supports the idea proposed by Leuckart that the aspidogastrids are sexually mature rediae. Wharton (1939) reported specimens of Lophotaspis vallei (Stossich, 1899) from the stomach of a large loggerhead turtle, Caretta caretta, taken in Gulf County, Florida. Young specimens of the same species, described as nymphs, were found in the conch, Fasciolaria gigas, from the same area. These mollusks are eaten by the turtle. According to Wharton, the emerged larva has eye-spots, oral and posterior suckers, three patches of cilia, and can both crawl and swim. Accordingly, the larvae can enter the mantle cavity of gastropods and develop into juveniles. Wharton noted that Lophotaspis macdonaldi Monticelli, 1891 is an immature individual from the Australian marine gastropod, Melo sp. Brinkmann (1957) reported on the development of Macraspis elegans. The eggs are embryonated in the uterus; the larvae on emergence lack cilia, have poorly developed anterior and well developed posterior suckers. He found a series of stages from very small specimens to fully mature ones in the gall-bladder of Chimaera monstrosa and concluded that $M$. elegans has a direct development without alternation of generations. However, he stated that the species may have an intermediary or transport host. This is indeed very probable; otherwise it is difficult to see how the emerged larvae could reach the final host.

Present knowledge shows the aspidogastrids to be primarily parasites of mollusks, but able to survive for considerable periods of time in predator hosts, e.g.; species of Aspidogaster, Cotylogaster and Lophotaspis in fishes and turtles. Moreover, certain of them, Stichocotyle nephropis, Multicalyx cristata, and Taeniocotyle elegans, have added intermediate, secondary or transport hosts in the life-cycle, although so far as known alternation of the sexual generation with an asexual one 
does not occur. The larvae emerge from the eggs as small distomes and often retain features characteristic of the rediae of digenetic trematodes, but are quite distinct morphologically from the larvae of the Monogenea which are limited to aquatic vertebrate hosts. Stunkard (1946) affirmed that the affinities of the aspidogastrids are clearly with the Digenea, although present information is insufficient to determine whether their life-cycle is primitive, or secondarily simplified. They constitute an aberrant, isolated group of parasites of mollusks and lower vertebrates which feed on such mollusks, and infect both marine and fresh-water hosts in all parts of the world. Members of the family form a homogeneous, coherent systematic group. Stichocotyle and Taeniocotyle agree in possessing a single row of alveoli and in this respect they differ from all other genera, whose members have three or four rows of alveoli. But Taeniocotyle has a single testis, a feature which it shares with Aspidogaster, Cotylaspis, Lissemysia, Lophotaspis and Lobatostoma, while Stichocotyle, Cotylogaster and Multicotyle have two testes. Many common features are shared and subdivision of the family is not justifiable.

As noted earlier, in his classification of 1892. Monticelli virtually divided the Digenea of van Beneden into the Aspidocotylea and Malacocotylea. It is evident that the aspidogastrids do not have a digenetic life-cycle and must be excluded from the Digenea. Accordingly, different authors have proposed to place them in a category intermediate between Monogenea and Digenea, but there is no intermediate condition. Either alternation of sexual and asexual generations does or does not occur in the life-cycle. Since the categories of Monticelli are merely rechristenings of the earlier ones of Burmeister, I propose to restore the original groups and arrange them in accord with morphological and developmental data. To this end, the Aspidogastridae and Digenea are included in a higher taxonomic unit, the subclass Malacobothridia Burmeister, 1856. The classification of the Pectobothridia appears generally acceptable but the arrangement of the Digenea is disputed by La Rue (1957) and Odening (1960). An incomplete system may be sketched as follows :

\section{Class Trematoda}

Subclass Pectobothridia Burmeister, 1856.

Firm, hard suckers, generally ectoparasitic on aquatic vertebrates and monogenetic; exceptions, Gyrodactylus and the polystomes of amphibians; one host.

Order Monopisthocotylea Odhner, 1912. Suborder Gyrodactyloidea Johnston and Tiegs, 1922.

Suborder Capsaloidea Price, 1936.

Order Polyopisthocotylea Odhner, 1912.

Suborder Polystomatoidea Price, 1936.

Suborder Diclidophoroidea Price, 1936.
Subclass Malacobothridia Burmeister, 1856.

Soft, flexible suckers; generally endoparasitic in invertebrates and vertebrates; begin life-cycles in mollusks; with $1,2,3$ or 4 hosts.

Order Aspidobothrea Burmeister, 1856.

Single family, Aspidogastridae Poche, 1907.

Order Digenea van Beneden, 1858.

Suborder Strigeatoidea Railliet, 1919. (= Order Strigeatoidea La Rue, 1926).

Suborder Echinostomatoidea Faust, 1929. (=) Order Echinostomida La Rue, 1957).

Suborder Plagiorchioidea Dollfus, 1930. (= Order Plagiorchiata La Rue, 1957).

Suborder Opisthorchioidea Faust, 1929. (=Order Opisthorchiata La Rue, 1957). 
Members of the Malacobothridia, like those of the Cestoda, begin their lifecycles as parasites of invertebrates, the former principally in mollusks, the latter in arthropods. Both groups are undoubtedly of great geologic age and there is evidence that present families have evolved together with their hosts (Stunkard, 1957). The cestodes are more degenerate or more highly specialized and more host-specific than the trematodes, and presumably have a longer parasitic history. Both groups are quite distinct from the Pectobothridia which have a distinctly different structure, different life-cycles, and presumably a different phylogenetic history.

It appears that the aspidogastrids and the digenetic forms have descended from a common turbellarian-like ancestor which initially was parasitic in mollusks; that the aspidogastrids never acquired asexual reproduction and become mature in the molluscan hosts or in vertebrates which feed on such hosts, whereas members of the Digenea developed polyembryonic asexual reproduction in the mollusk and with the acquisition of vertebrate hosts, sexual maturity was more and more deferred to worms in the definitive hosts. Acquisition of the longer-lived, widerranging vertebrate hosts facilitated dispersal and prolonged the life of the parasites, thus increasing reproductive capacity and survival value of the species. The frequent appearance of progenesis and the demonstration (Stunkard 1959, 1960) that the life-cycle of Asymphylodora amnicolae can be completed in the snail without the intermediation of the usual vertebrate host, lend support to the thesis that originally the Digenea were parasites of mollusks and that secondarily they acquired vertebrate hosts.

\section{SUMMARY}

Taeniocotyle nom. nov. is proposed to replace Macraspis O1sson, 1869, homonym of Macraspis MacLeay, 1819, a coleopterous insect. It designates certain trematode worms, from the gall-bladders of selachian fishes, that belong to the family Aspidogastridae Poche, 1907 and the order Aspidobothrea Burmeister, 1856. The systematic position of this group, often regarded as intermediate between the Monogenea and Digenea, is reviewed. From morphological and developmental evidence, the Aspidobothrea and Digenea are included in the subclass Malacobothridia Burmeister, 1856.

\section{LITERATURE CITED}

Aubert, A., 1855. Ueber das Wassergefässsystem, die Geschlechtsverhältnisse, die Eibildung und die Entwicklung des Aspidogaster conchicola mit Berüchsichtigung und Vergleichung anderer Trematoden. Zeitschr. wiss. Zool., 6: 349-376.

van Beneden, P. J., 1858. Mémoire sur les vers intestinaux. C. R. Acad. Sci. Paris, Suppl. 2: $376 \mathrm{pp}$.

Brandes, G., 1890. Die Familie der Holostomiden. Zool. Jahrb., Syst., 5: 549-604.

Braun, M., 1893. Vermes. In: Bronn's Klass. u. Ordnung d. Thierreichs, 4 (Abt. 1) : 817925.

Breder, C. M., Jr., 1929. Field Book of Marine Fishes of the Atlantic Coast. 332 pp. Putnam's Sons, New York.

Brinkmann, August, JR., 1957. Fish trematodes from Norwegian waters. Universitetet Bergen Arbok, 1957 (4) : 1-29.

Burmeister, K. H., 1856. Zoonomische Briefe. Allgemeine Darstellung der thierischen Organization. Vol. 2: 1-470. Leipzig. 
Carus, J. V., 1863. Räderthiere, Würmer, Echinodermen, Coelenteraten und Protozoen. In: Handbuch d. Zool. (Peters, Carus u. Gerstaecker), 2: 422-600.

Dawes, B., 1941. On Multicotyle purvis n.g., n. sp., an aspidogastrid trematode from the river turtle, Siebenrockiella crassicollis, in Malaya. Parasitol., 33: 300-305.

Dollfus, R. P., 1956. Système de la sous-classe des Aspidogastrea E. C. Faust et Tang, 1936. Ann. Parasitol., 31: 11-13.

Dollfus, R. P., 1958. Sur Macraspis cristata (E. C. Faust et C. C. Tang, 1936) Manter, 1936 et sur une émendation nécessaire à ma définition de la famille des Aspidogastridae. Ann. Parasitol., 33 : 227-231.

Faust, E. C., 1922. Notes on the excretory system in Aspidogaster conchicola. Trans. Amer. Micros. Soc., 41: 113-117.

Faust, E. C., And C. C. TAng, 1936. Notes on new aspidogastrid species, with a consideration of the phylogeny of the group. Parasitol., 28: 487-501.

Grobben, K., 1879. Die Entwicklungsgeschichte der Moina rectirostris. Arb. zool. Institut Univ. Wien, 2: 203-263.

Grobben, K., 1882. Doliolum und sein Generationswechsel nebst Bemerkungen über den Generationswechsel der Acalephen, Cestoden und Trematoden. Arb. zool. Institut Univ. Wien, 4 : 201-298.

Hyman, Libbie H., 1951. The Invertebrates. Vol. 2, 550 pp. McGraw-Hill Book Co., New York.

JäGerskiöLd, L. A., 1899. Ueber den Bau von Macraspis elegans Olsson. Öfv. Ak. Förh., 56 : 197-214.

LA Rue, G. R., 1957. The classification of the digenetic Trematoda: a review and a new system. Exper. Parasitol., 6: 306-344.

Leuckart, K. R., 1863. Die Parasiten des Menschen und die von ihnen herrührenden Krankheiten. Bd. 1: 766 pp. Leipzig.

Leuckart, K. R., 1879. Die Parasiten des Menschen und die von ihnen herrührenden Krankheiten. 2 Aufl, Bd. 1:(Abt. 1) : 336 pp. Leipzig u. Heidelberg.

Leuckart, K. R., 1882. Zur Entwicklungsgeschichte des Leberegels (Distomum hepaticum). Arch. Naturg., 48 (1) : 80-119.

Leuckart, K. R., 1889. Die Parasiten des Menschen und die von ihnen herrührenden Krankheiten. 2 Aufl. Bd. 1: 97-440. Leipzig.

von Linstow, O. F., 1877. Enthelminthologica. Arch. Naturg., 43: 173-198.

Lutz, A., 1921. Zur Kenntnis des Entwicklungszyklus der Holostomiden. Zentralbl. Bakt. I. Orig., 86: 124-129.

Manter, H. W., 1931. Some trematodes of marine fishes of Beaufort, North Carolina. Parasitol., 23 : 396-411.

Manter, H. W., 1954. Some digenetic trematodes from fishes of New Zealand. Trans. Roy. Soc. N. Z., 82: 475-568.

Mathias, P., 1922. Cycle évolutif d'un trématode holostomide (Strigea tarda Steenst). C. R. Acad. Sci., Paris, 175: 599-602.

Monticelli, F. S., 1888. Saggio di una morfologia dei Trematodi. Napoli; 130 pp.

Monticelli, F. S., 1892. Cotylogaster michaelis n.g., n.sp. e revisione degli Aspidobothriidae. Festschr. 70 Geburtst. R. Leuckart, pp. 168-214.

Najarian, H. H., 1961. New aspidogastrid trematode, Cotylaspis reelfootensis, from some Tennessee mussels. J. Parasitol., $47:$ 515-520.

Neave, S. A., 1940. Nomenclator Zoologicus, $3: 7$.

Nickerson, W. S., 1895. On Stichocotyle nephropis Cunningham, a parasite of the American lobster. Zool. Jahrb., Anat., 8: 447-480.

Odening, K., 1960. Zur Grosseinteilung der digenetischen Trematoden. Zeitschr. Parasit., $20: 170-174$.

OdHner, T., 1898. Über die geschlechtsreife Form von Stichocotyle nephropis Cunningham. Zool. Anz., 21: 509-513.

ODHNER, T., 1902. Trematoden aus Reptilien nebst allgemeinen systematischen Bemerkungen. Öfv. Ak. Förh., 59: 19-45.

Olsson, P. J., 1869. Nova genera parasitantia Copepodorum et Platyelminthium. Lunds Univ. Arsskr., afd. Math. o. Naturv., 6: 1-6. 
Osborn, H. L., 1904. On the habits and structure of Cotylaspis insignis Leidy, from Lake Chautauqua, New York. Zool. Jahrb., Anat., 21: 201-243.

Ruszkowski, J. S., 1922. Die postembryonale Entwicklung von Hemistomum alatum. Bull. internat. Acad. Cracovie, ser. 3, 61: 249-254.

Schäller, G., 1960. Beitrag zum Problem der Keimzellenbildung bei Trematodenlarven. Zeitschr. Parasitenk., 20: 146-151.

Sinitsin, D. F., 1911. The parthenogenetic generation of the trematodes and their descendants in the Black Sea mollusks. (Russian text) Mém. Acad. Imp. Sci., St. Petersb., ser. 8, 30 (5) : 1-127.

Steenstrup, J. J. S., 1842. Ueber den Generationswechsel oder die Fortpflanzung und Entwicklung durch abwechselnde Generationen, eine eigenthümliche Form der Brutpflege in den niederen Thierclassen. 140 pp. Copenhagen. (German translation by C. H. Lorenzen).

Stiles, C. W., And A. Hassall, 1908. Index-Catalogue of Medical and Veterinary Zoology: Trematoda and Trematode Diseases. Bull. No. 37, Hygienic Laboratory, Washington, D. C.

Stunkard, H. W., 1917. Studies on North American Polystomidae, Aspidogastridae and Paramphistomidae. Illinois Biol. Monogr., 3 (3) : 1-115.

Stunkard, H. W., 1940. Life-history studies and the development of Parasitology. J. Parasitol., 26: 1-15.

Stunkard, H. W., 1946. Interrelationships and taxonomy of the digenetic trematodes. Biol. Reviews (Cambridge), 21: 148-158.

Stunkard, H. W., 1957. Host-specificity and parallel evolution of parasitic flatworms. Zeitschr. Tropenmed. u. Parasitol., 8: 254-263.

Stunkard, H. W., 1959. Progenesis in digenetic trematodes and its possible significance in the development of present life-histories. Biol. Bull., 117: 400-401.

Stunkard, H. W., 1960. The morphology and life-history of the digenetic trematode, Asymphylodora amnicolae n. sp.; the possible significance of progenesis for the phylogeny of the Digenea. Biol. Bull., 117: 562-581. (December 1959 issue).

Thomas, A. P. W., 1883. The life history of the liver fluke (Fasciola hepatica). Quart. J. Micros. Sci., n.s., (89) $23: 99-133$.

Van Cleave, H. J., and C. O. Williams, 1943. Maintenance of a trematode, Aspidogaster conchicola, outside the body of its natural host. J. Parasitol., 29: 127-130.

Voeltzkow, A., 1888. Aspidogaster conchicola. Arb. zool. zoot. Inst. Univ. Würzburg, pp. 249-289.

Wharton, G. W., 1939. Studies on Lophotaspis vallei (Stossich, 1899) (Trematoda: Aspidogastridae). J. Parasitol., $25: 83-86$.

Williams, C. O., 1942. Observations of the life history and taxonomic relationships of the trematode Aspidogaster conchicola. J. Parasitol., 28: 467-475. 


\section{$2 \mathrm{BHL}$ Biodiversity Heritage Library}

Stunkard, Horace Wesley. 1962. "TAENIOCOTYLE NOM. NOV. FOR MACRASPIS OLSSON. 1869. PREOCCUPIED, AND SYSTEMATIC POSITION OF THE ASPIDOBOTHREA." The Biological bulletin 122, 137-148.

https://doi.org/10.2307/1539327.

View This Item Online: https://www.biodiversitylibrary.org/item/17355

DOI: https://doi.org/10.2307/1539327

Permalink: https://www.biodiversitylibrary.org/partpdf/14484

\section{Holding Institution}

MBLWHOI Library

\section{Sponsored by}

MBLWHOI Library

\section{Copyright \& Reuse}

Copyright Status: In copyright. Digitized with the permission of the rights holder.

License: http://creativecommons.org/licenses/by-nc-sa/3.0/

Rights: https://biodiversitylibrary.org/permissions

This document was created from content at the Biodiversity Heritage Library, the world's largest open access digital library for biodiversity literature and archives. Visit BHL at https://www.biodiversitylibrary.org. 